\title{
INTRA-PARTY RESTRUCTURING IN THE CONDITIONS OF POLITICAL TRANSIT IN UKRAINE
}

\author{
Kroitor A. V.
}

\section{INTRODUCTION}

In light of current political processes linked to the desire to democratize the political system, the need to restructure party structures in Ukraine plays an important role. Political parties in the context of transit to democracy remain perhaps the most important institution of representative democracy, playing the role of mediator between society and the state on the one hand, and on the other it is not the only significant institution of articulation and aggregation of public interests in the political system. In addition, as part of the mobilization of the masses, the parties ensure their conventional participation in the political process, which ensures the stability of the political system. Through participation in the electoral process, political parties ensure the legitimization of the political system, which ensures its stability.

However, the question of the democratization of party structures remains open, since legitimization of the party elite is not possible in the conditions of maintaining a centralized party structure, with limited influence of ordinary members on the political decision-making process. On the other hand, the question arises as to the effectiveness of the party organization in the inter-party struggle for electoral capital.

The process of forming a multi-party political system in Ukraine in the first stage after the proclamation of Independence is conditioned by the absence of political pluralism, a one-party political system.

According to the opinion of the Ukrainian author B. Gagalyuk, «Modern Ukrainian political parties were formed earlier than formed by social groups, so objectively could not find clear social addresses, become expressions of interests of particular social strata. We should note today the isolation of groups of parties that claim to be sympathetic to virtually the entire 
electorate and, at the same time, function as «business projects» designed to unite and lobby the interests of certain political and economic groups» ${ }^{1}$.

At the same time, it should be noted that the party system of the country is gradually evolving from a one-party to a multi-party system of polarized pluralism with a pronounced regional division, which increases the competition of political parties for control over public authorities.

The characteristics of the modern party system include: increasing the role of parties in the political process, in particular - in parliamentary activities; positioning of political parties, their distribution by the criterion «pro-government - opposition»; formation of a «party of power». In the current context, there is a process of creating party structures based on centers of influence organized around state power institutions; the problem of transforming election technologies into political party activities into an effective democratic governance strategy after the party has gained power; general uncertainty about political ideologies, both in public opinion and in the activities of party structures, the blurring of the right-center-left scale results in the creation of quasi-party groups.

It is a simulation of ideology, which is expressed even in the names of some Ukrainian parties. At the same time, the processes of «ideologizing» political space have two interrelated contexts. On the one hand, postcommunist, when society was tired of the domination of a single totalitarian communist ideology that defined activity in all spheres of public life - from sport and culture to economy and politics.

On the other hand, there are contemporary world-wide transformations of ideologies, under the influence of which the very concept of ideology changes and ceases to be a mere political doctrine; - structuring of political parties around leaders («rating locomotives»), personalization of election campaigns of parties.

Thus, in the process of forming democracy, as an actual form of political interaction in the activities of political parties, one of the main contradictions of the transition period is fully manifested: between full representation of the interests of different social groups and a structured and capable parliament. Obviously, the legitimacy of the government and its political decisions depends on how adequate the representation of group interests in parliament is. However, polarizing the views of political actors and their representation in parliament can slow down or make law-making processes impossible.

1 Гагалюк Б. Концепт «правлячої партії» в умовах парламентаризму: сучасний політичний дискурс. Нова парадигма: Журнал наукових праџь. 2006. Вип. 55. Київ, Вид-во НПУ імені М. П. Драгоманова. С. 152-161. 


\section{Intra-party interaction as a factor of democratization of the political system in Ukraine}

Formation of democracy in the state is complicated by the absence of democratic rules of the game in intra-party interaction. Political parties (ruling or opposition), if they really seek to establish a democratic system in the state, are bound to uphold and protect democratic values and human rights, above all in political parties and intra-party interaction.

The formation of a democratic model of intra-party interaction is complicated by the following factors: limitations and difficulties in the process of horizontal and vertical communication; lack of professional and effective political management; authoritarian style of party leadership; unlimited tenure of office and leadership of the party; insufficient level of political activity and political participation of citizens during the election period; a totalitarian ideology that remains the basis of the programs and activities of some (left and right) parties.

Democracy in party activity is based on the principle of involvement of party members in the party decision-making process, taking into account the political purpose of party activity and party ideology. Freedom of expression of party members, involvement of party members in political activity during election and inter-election periods, gender equality, toleration and tolerance in party relations, defined decision-making procedure, accountability of leaders, etc. The implementation of democratic principles implies publicity and transparency at all stages of the decision-making process, which may conflict with the need for a public demonstration of the party unity sought by each party. That is why the party activity combines the principles of publicity and discussion about the political decision and defines the procedure for its adoption and approval by the party leadership.

Democratization of internal party relations is impossible without effective mechanisms of control by the public, ordinary party members, mass media led by parties. In democratic parties, this is ensured by the presence of powerful party organizations (outlets) on the ground, an extensive network of party representation in all constituencies. At all levels from the community, the district, the region to the capital central office general meetings and meetings of party members, delegates should ensure that the heads of power structures of the respective levels can rely on the mandate given to them democratically.

Each party chooses the mechanism of involvement of ordinary party members in making important decisions and in controlling the activities of the party apparatus. For example, the so-called «women's quota» was set up 
in the Social Democratic Party of Germany when up to 50\% of all party positions and mandates are given to women ${ }^{2}$.

The study of the problems of internal party democracy is one of the main areas of political analysis of the political parties activities. The basis for scientific research on intra-party democracy is the famous iron «law of oligarchy» by R. Michels, who initiated the study of the interaction between the party oligarchy and the masses. ${ }^{3}$

Despite the huge amount of comparative analysis of the internal party structure, there is no consensus in political party studies on clear criteria for assessing democracy and its minimum required so that the party does not lose development dynamics and turn into a regular debate platform.

Within the research of the party model based on the theory of public choice and economic approach to the analysis of political activity, widespread and constant participation of party members in internal party politics and in the recruitment of personnel is considered as a malfunction (dysfunction), because it requires adequate resources, which can be directed to inter-party struggle. In addition, political activity limits the freedom of action of the party leadership and reduces the effectiveness and flexibility of the party organization aimed at achieving the main goal - obtaining the maximum number of votes. The optimal use of the chances of winning the election requires the effective use of available resources (time, people, money, etc.), and this can best be achieved by centralizing power and concentrating decision-making powers in the hands of voter-oriented party leadership. In this way, the formation of intra-party willpower from top to bottom can be achieved.

Based on a model of democracy aimed at satisfying the need to ensure the existence and efficiency of the political system, the whole-systemoriented perspective gives a different scale to assessing the formation of inner-party will. The organizational model of political parties that are relevant to this view is representative, open, responsible, pluralistic, and legitimized by elite domination within the party. This conception of intraparty democracy is based on the premise that «the structure of parties can

${ }^{2}$ Політичні партії України: погляд фахівців. Національна безпека $і$ оборона. 2015. № 6-7. C. 155-156. URL: http://www.razumkov.org.ua/uploads/journal/ukr/NSD155156_2015_ukr.pdf.

3 Лебедюк В. Організаційний баланс ресурсів політичних партій в Україні. Наиіональна бібліотека Украӥни імені B. I. Вернадського: веб-сайт. URL: http://dspace.nbuv.gov.ua/bitstream/handle/123456789/26799/15-Lebedyuk.pdf?sequence=1 . 
only be representative,» as well as on the principle of elite intra-party competition $^{4}$.

The decisive factor of intra-party interaction in the process of political transformation is not the constant communication flow of the formation of ideological and political will from the bottom up, but the election, control, elimination and replacement of intra-party representatives.

Within a democratic model that focuses on the need for legitimation, intra-party democracy is achieved through unrestricted participation of party members in the processes of internal party policy-making. The basis of this concept is the model of formation of inner-party wills from the bottom up, which is clearly oriented to the opinion of ordinary party members. According to this concept, political participation is not limited to simple «participation in organizational matters», but means "participation in decision-making», that is, real participation in binding intra-party decisions at any level of the organization. This concept is inextricably linked to the introduction of an imperative mandate for people`s deputies of all levels.

Based on an intra- party democratic model focused solely on the interests of ordinary party members, any real power within the parties will be essentially undemocratic. At the same time, the analysis is focused mainly on the model of division into ordinary party members and leadership, where the concepts of «leadership» and «oligarchy» become synonymous, and the focus is on the separation and alienation of party elites from other party members. In general, the following criteria are used to assess the state of intra-party democracy: the participation of party members in intra-party work, the participation of party members in policy-making, the participation of party members in the selection of candidates, and the nomination of candidates for elected office.

The internal structure of the party is understood as the organization of the processes of forming the internal party course and political decision-making. In their activities, political parties must adhere to the rules of current law. As a rule, they are free to identify issues regarding their organizational structure, except for certain provisions that are subject to legal regulation in accordance with the law.

The Constitution of Ukraine gives citizens the right to freedom of association in political parties and public organizations to exercise and protect their rights and freedoms and to satisfy political, economic, social,

${ }^{4}$ Плахтій Т. Концепція і стратегія реструктуризації політичних партій в Україні. 2016. 19 жовтня. Хвиля: веб-сайт. URL: http://hvylya.net/analytics/society/kontseptsiyai-strategiya-restrukturizatsiyi-politichnih-partiy-v-ukrayini.html. 
cultural and other interests. ${ }^{5}$ The Law of Ukraine «On Political Parties in Ukraine» puts forward such requirements for the party as all-Ukrainian status, fixed membership, voluntary activity, compulsory registration of an organization with central governing bodies and local branches, program and charter, name, symbolism and registration in the Ministry Justice of Ukraine $^{6}$.

However, domestic legislation does not require political parties to elect and collegial the work of governing bodies, to observe the territorial principle of organizing party structures, to hold conferences periodically, and does not specify the maximum terms of office of party governing bodies and its regional offices.

By defining the rules of political game, the state regulates legislatively issues related to both the functioning and organizational construction of the party. It makes clear requirements for structure, size, territorial scale, election activity, etc.

The party charter fixes the forms of organization, methods of party work and principles of intra-party interaction. The processes of forming a hierarchy within the party, the structure of vertical and horizontal interaction are enshrined in the norms of the charter of a political party.

So, the charter defines the authority of the party congress. If we look at the party charters of the Ukrainian parties, we can see some differences in the interpretation of the role and place of the party congress in the intra-party interaction. So, the chart of the Party of Regions stated that more than half of the elected delegates were sufficient to consider the congress to be authorized. Decisions at the convention shall be taken by a majority vote of the delegates present, except for matters on which the present charter provides for a different decision-making procedure ${ }^{7}$. The same norm is enshrined in the charters of the Socialist Party of Ukraine, the People's Democratic Party and others.

The All-Ukrainian Union «Batkivshchyna» has set other statutory rules for congressional authority. The congress is valid if at least $2 / 3$ of the elected delegates participate in its work ${ }^{8}$. The party's charter contains a rule on the C. 141 .

5 Конституція України від 28.06.1996 р. Відомості Верховної Ради. 1996. № 30.

${ }^{6}$ Про політичні партії в Україні: Закон України від 05.04.2001 р. № 2365-III (зі змінами). Офіційний сайт Верховної Ради Украӥни. URL: http://zakon2.rada.gov.ua/laws/ show/2365-14.

${ }^{7}$ Статут Партії регіонів. Офіиійний сайт украӥнської партї Партія Регіонів». URL: http://www.partyofregions.org.ua/meet/statute/.

${ }^{8}$ Статут Всеукраїнського об'єднання «Батьківщина». Офіційний сайт украӥнської партії «Батьківщинау. URL: http://byut.com.ua/statute.html. 
co-optation of governing bodies (the introduction of new members without additional elections), which violates the principle of election: In the period between congresses, the Political council of the party may, if necessary, within the limits determined by the Congress of the Political council, co-opt its authoritative members of the party and to remove from the Political council those members who are not actively involved in the work or have lost contact with the party»" ${ }^{9}$.

Not all political parties in Ukraine reflect in their charters the norms of activity of deputies of different levels, and when moving to work in state authorities and local self-government, a party member suspends its membership. The harsh conditions of internal party relations are dictated by the provisions of the All-Ukrainian association «Svoboda», which also does not contribute to the democratization of intra-party life. In particular, decisions on the nomination of candidates are made by the party chairman and the party's leading structural units. The party court institute was created in the party. Thus, the charter states that the Party court of UU «Svoboda» (hereinafter referred to as the PC) is a separate structure within the party, which is intended for consideration of complaints, allegations and conflicts of intra-party nature. The Congress of UU «Svoboda» is elected by the Chairman of the Party court of UU «Svoboda». The members of the UU «Svoboda» are elected by the Congress of UU «Svoboda» upon the submission of the Chairman of UU «Svoboda». The provision presented demonstrates the role of the party congress in making personnel decisions.

The charter of the political party «UDAR» (Ukrainian Democratic Alliance for Reforms) of Vitaliy Klichko» declares that the party acts on the principles of voluntariness, equality and mutual respect of its members, collegiality of leadership, observance of internal party discipline and democracy, self-government, legitimacy. Paragraph 9 of the party`s charter states that the procedure for nominating candidates for deputies of the Verkhovna Rada of the Autonomous Republic of Crimea, local councils, candidates for the position of village, settlement, city mayors by local party organizations shall be determined by the Political Council of the Party or the Party Congress. It is stated that the procedure for approving the election programs of candidates for deputies of the Verkhovna Rada of the Autonomous Republic of Crimea, local councils, candidates for the position of village, settlement, city mayors shall be determined by the Political Council of the Party or the Party Congress. These provisions contain important provisions on the democratic procedure for the nomination of candidates for a party by a party congress, which enables the ordinary

\footnotetext{
${ }^{9}$ Ibid.
} 
members of the party to be involved in the procedure for nominating candidates for deputies.

However, in the charters of political parties in Ukraine, insufficient attention is paid to the mechanisms of increasing the activity of ordinary party members and their involvement in the process of party decision making (in particular, regarding the nomination of candidates for deputies). At the same time, the organizational and political functions of the Party Congress are often duplicated by the powers of the Political Council of the Party and the executive committee, which are essentially in charge of intraparty relations.

Analyzing the statutory documents of modern political parties, we can agree with I. Zhdanov's conclusion about the significant influence of the Soviet past on the activities of political parties in Ukraine: «A key feature of the evolution of political parties in Ukraine (as in most post-Soviet countries) is that the CPSU has been and remains the main model for the way of formation, drafting of documents, registration, logic of internal system functioning and specificity of participation in political processes ${ }^{10}$.

One of the main reasons for the closeness of party decision-making and the opacity of intra-party interaction is the problem of financial support for both the current activity of party structures and the party's participation in election campaigns. In these circumstances, the political space is dominated by «leadership» type parties that represent the interests of certain financial and industrial groups. It is worth agreeing that «only one function is $100 \%$ fulfilled - the struggle for power» ${ }^{11}$. One of the reasons for the lack of internal party democracy in the modern political parties of Ukraine is the low level of political activity and participation of citizens and party members in the development, adoption and implementation of internal party politics.

In the electoral period, the activities of a political party are aimed at achieving a certain result, which involves taking into account public opinion, voter motives. One of the main factors capable of supporting voters is the activity of the party leader (the «rating engine» that heads the party's electoral list).

On the one hand, identifying a party with a leader facilitates the positioning of a political party in the electoral space, streamlines the choice of citizens, reducing it to the parameter of evaluating the leader's activity, simplifies it. On the other hand, it encourages the creation of leadership-type

10 Жданов I., Якименко Ю. Нові обрії української багатопартійності. Дзеркало тижня. 2003. № 24. URL: http://gazeta.dt.ua/POLITICS/novi_obriyi_ukrayinskoyi_ bagatopartiynosti.html.

${ }^{11}$ Ibid. 
parties with authoritarian internal organization and focuses the party's election campaign solely on the personality of the leader and his promises, not ideology and programmatic foundations.

To this should be added the process of blurring the ideological base, the convergence of ideologies, which also causes problems for the democratization of party and political interaction, and turns even ideological parties into «voting machines». The intra-party struggle is focused not on ideological discussions, but on defining the leader and asserting his influence, slows down unification processes and the creation of large nationwide parties.

The lack of a defined effective model of intra-party interaction leads to permanent crises in the political party, loss of electoral support and disintegration. The lack of institutionalization of intra-party democracy leads to failures in the system of evolutionary change of party leadership, and consequently to the development of a political party. An example is the situation with a number of schisms in the Political Party «Nasha Ukraina» (formerly called the People's Union «Nasha Ukraina»). So, « the intra-party relations in «Nasha Ukraina», although not marked by the particular dictate of the party leader, but had a typically oligarchic structure of interaction where the party leadership restricted the real functioning of intra-party democracy, as evidenced by the procedure for nominating candidates for deputies. The loss of power by the party caused tensions in the intra-party struggle that spilled over into divisive congresses.

For example, the former chairman of the Political Council of «Nasha Ukraina» Sergiy Bondarchuk said that in the 2012 parliamentary elections, the party fulfilled a «technical task in the interests of the Party of Regions $\rangle^{12}$. On February 9, 2012, Bondarchuk announced his removal from the party of Honorable President Viktor Yushchenko. March 2 Congress «Nasha Ukraina» chaired by S. Bondarchuk decided to liquidate the party. However, part of V. Yushchenko's supporters gathered for an alternative congress, expelling S. Bondarchuk from the party, which gave reason to the Ministry of Justice of Ukraine refused to register the submission of the chairman of the political council of the Party «Nasha Ukraina» on the termination of the party's activity. The political process of intra-party struggle illustrates the tensions in the party, the complexity of the processes of democratization of interaction between members of the political party horizontally and vertically.

12 3'їзд Бондарчука прийняв рішення про саморозпуск «Нашої України». Дзеркало тижня. 2012. 2 брезня. URL: http://zn.ua/POLITICS/sezd-bondarchuka-prinyal-reshenieo-samorospuske-nashey-ukrainy-118067_.html. 
As an example of forming an effective model of intra-party interaction, we can cite the activity of the Party of Regions, which gained power due to the well-considered position of the party leader regarding various groups of influence and the rigid organizational structure of intra-party interaction during the election period.

Considering the former Party of Regions in terms of intra-party relations, it should be noted that it was a «hierarchical political organization with strong centralism and influence of the party leader on the political decisionmaking process $\rangle^{13}$. This is a prominent party-type party whose leader became the President of Ukraine (as the first party president, not just an honorary party leader). This indicates an increase in the influence of parties in the political system. It is worth noting that the political parties of Ukraine are characterized by an image attachment to its leader, since after V.F. Yanukovych to the Russian Federation, the Party of Regions lost its leader and ceased to exist.

It can be argued that the process of intra-party interaction is characterized by an increasing role of the leader in forming the party organization, control over the processes of personnel rotation by the party leadership, exacerbation of conflicts within the parties during the election period, when there is a distribution of seats in the party lists. The development of intraparty interaction demonstrates a certain dependence of the state of internal democracy in parties on the level of political culture (not only in parties, but also in society as a whole). The activities of party structures are affected by the contradictory nature of society's development.

The main principles of intra-party democracy in the transition period are the election of governing bodies, periodic reporting of leadership to ordinary party members, collegiality in the work of governing bodies, personal responsibility of each party member for the performance of duties and powers, the supremacy of the congress as expression of the will of the whole party, democracy at the stage of discussion and discipline in the implementation of decisions after its adoption, bottom-up criticism, publicity and public nature of the action ${ }^{14}$.

An important component of intra-party interaction is the activity of party leaders, who often play a decisive role in the process of developing and implementing organizational strategies of political parties. Functional features of the party leader's activity consist in the ability to compensate for

13 За часів президентства Януковича ПР перетворилася на аналог радянської партії. Правда. 2013. 18 березня. URL: http://pravda.if.ua/print.php?id=37382.

${ }^{14}$ Кройтор А. В. Полухіна А. В. Реструктуризація внутрішньопартійної організації як виклик сучасної доби. Актуальні проблеми політики. 2017. Вип. 60. С. 223-234. 
the low efficiency of the party's organizational, human and program resources. The phenomenon of party leadership implies the primacy of the individual in government structures, political parties and pressure groups.

\section{Restructuring of political parties of Ukraine in the conditions of democratization}

Among the problems of the implementation of the intra-party process there are the following provisions:

Firstly, the primary focuses on reviewing and evaluating party documents and strategies proposed by management; delegates their representatives to party congresses; makes proposals for candidates for deputies of Ukraine. Candidate lists are «batch-approved» by party congresses. However, the procedure for forming the lists of candidates for deputies of Ukraine is not clearly spelled out either in the statutory documents of political parties or at the legislative level. Under the charters of some parties, considerable powers are conferred on governing bodies. However, only in some cases it is assumed that the governing bodies of the parties are made taking into account the regional representation.

Secondly, party leaders seek conservatism and strengthen their power by concentrating several positions in the party apparatus.

Thirdly, party leaders seek to prevent ordinary members from making decisions, creating the illusion of their participation.

The traditionally predetermined electoral orientation of the Ukrainian population to personalize the political process and party organizations leads to an increased role of the leader. Increasing the role of party leader may result in a tendency that manifests in the inclination of party leaders to concentrate power in their hands. Such a development of party life will inevitably lead to the party's transformation into a rigid, authoritarian, closed structure to serve the interests of party leadership and, as a consequence, to its split in the future. Conflict may be triggered by the influence of new activists, who may be more powerful than the «old» functionaries, with significant restrictions on party careers.

Intra-political conflicts «can occur at different levels of party functioning: at the level of central leadership, within grassroots organizations, between grassroots party organizations and the center» ${ }^{15}$.

In recent decades, another important trend has clearly emerged in party activities. Regardless of political ideology and internal party structure, political parties began to focus in their activities on communicative

${ }^{15}$ Шведа Ю. Р. Теорія політичних партій і партійних систем. Львів: ЦПД, 2002. 528 с. 
technologies of influence on society (political advertising, propaganda, political PR). Gradually, this global trend has spread to Ukraine, creating the conditions for politicization of politics, transformation of politics into a media process, emergence of phenomena of «real virtuality» and «virtual democracy». Political parties, like ordinary companies that want to sell their goods, hold party events as PR promotions. First and foremost, it is about staging and directing party congresses that turn into a live show and are being shown live. At the same time, experts note that during such congresses, you can see many elements, the sources of which reach back to the Soviet traditions of celebrations.

With such a visual appeal, the intra-party activities of elites and leaders are characterized by secrecy, conflicts do not become public, and are ignored by official websites and other media resources of the parties. As a rule, party leaders, related to financial and economic interests, silence disputes that occur in intra-party interaction.

Functional features of the process of intra-party interaction at the present stage are also determined by the following factors.

Firstly, political parties are focused not on ideology, but on the communication technologies of organizing political (especially election) campaigns. Political parties' programs have a contradictory combination of liberal principles in the party's economic and political doctrine and socialist and paternalistic provisions (promises of wages and pensions, abolition of pension reform, etc.).

Secondly, the Law of Ukraine on Civil Service No. 4050-VI, which forbids public servants from membership in political parties, is directly related to domestic political activity. A civil servant is required to terminate membership of a political party prior to his or her appointment. The ban on the party affiliation of a civil servant and the need to leave the party immediately after his or her appointment, on the one hand, complicates the participation of a civil servant in elections, and on the other, it deprives political parties of a large layer of educated, qualified individuals, who in many cases form the core of the party organization itself. The aspirations of civil servants to be elected, as well as the interest of political parties in their list of influential, and in some places well-known officials, will inevitably transfer relations between officials and political parties into the informal shadow sphere.

To overcome the oligarchization of the party structure, a prerequisite is the provision of the possibility of influence of ordinary party members on party politics, nomination of candidates in internal party elections, transparency of the decision-making process at the local and central levels of 
the party organization, freedom of intra-party debate, criticism of party organs, in fact, and the basis of intra-party democracy. Thus, in the process of democratization of Ukrainian society an important role belongs to the mechanisms of building of intra-party relations on the basis of democratization.

M. Oferle views political parties as companies that are struggling to make a profit. Thus, the parties as an entrepreneur in the market should exchange their ideas, values, statements in the program in support of the electorate. It is because of this support that the party gains power, and therefore not only the effectiveness of the election campaign, but also the further development of the party depends on a rationally organized internal party structure.

Therefore, the restructuring of a party organization should be understood as qualitative changes in the internal party structure, the introduction of which will not only democratize intra-party interaction, but also enhance the competitiveness of the party in the party market in the struggle for electoral capital. The concept of restructuring, as T. Plakhtiy points out, is the idea of a systematic analysis that the external qualities of systems, in particular the social ones, which are organizations, are determined by their structure. That is, in order to change the qualities of an organization, it is necessary to change its structure or, in other words, to carry out its restructuring.

G. Morgan determines that the effective structure of any organization in a market environment is determined primarily by the challenges facing the organization. That is, in conditions of stable functioning, when the external environment does not form new requirements, the organizational structure has a hierarchical system of formal positions that ensures the day-to-day management of the organization. In addition, the responsibility for the performance of each actor depends on his place in the hierarchy, that is, the higher the level of the organizational pyramid is held by the person, the higher the level of his responsibility in the system of making and implementing intra-structural decisions ${ }^{16}$. With the changing environment that creates new challenges to the system, the management system should be changed towards decentralization and redistribution of roles within the organization.

Considering the structure of domestic parties, it becomes clear that they are centralized and rigidly hierarchized organizations with limited levels of intra-party democracy. This is evidenced by the statutory documents of the

${ }^{16}$ Плахтій Т. Концепція і стратегія реструктуризації політичних партій в Україні. 2016. 19 жовтня. Хвиля: веб-сайт. URL: http://hvylya.net/analytics/society/kontseptsiyai-strategiya-restrukturizatsiyi-politichnih-partiy-v-ukrayini.html/ 
parties. In particular, the party charter fixes the forms of organization, methods of party work and principles of intra-party interaction. The processes of forming a hierarchy within a party, the structure of vertical and horizontal interaction are enshrined in the norms of the charter of a political party.

Also in the charters of political parties in Ukraine, insufficient attention is paid to mechanisms of increasing the activity of ordinary party members and their involvement in the process of party decision-making (in particular, regarding the nomination of candidates for deputies). At the same time, the organizational and political functions of the party congress are often duplicated by the powers of the Political Council of the party and the executive committee, which are essentially in charge of intra-party relations.

One of the main reasons for the closeness of party decision-making and the opacity of intra-party interaction is the problem of financial support for both the current activity of party structures and the party's participation in election campaigns.

At the present stage of development of the political system of Ukraine, there is a transformation of the party system related to the return to the parliamentary-presidential republic, which envisages the formation of a coalition in parliament for the purpose of forming a government, and changes in the electoral system. However, there remains a tendency to dominate leadership-type parties that represent the interests of certain financial and industry groups. At the same time, there are two exceptions to this trend.

Firstly, the political party «Opposition Bloc», formed on the remnants of the once influential Party of Regions with the loss of a «leader-face» and the inability of one of the party's new leaders to embody a party brand, offered such a phenomenon as party co-ordination.

Secondly, from the context of leadership parties, the Ukrainian Patriots Union - «Ukrop», which, although has a formal leader, stands out, but in the public consciousness, its image is not identified with the political party brand. In addition, it should be noted that the new changes to the wording of the charter of a political party indicate a certain, well-considered tendency to democratize intra-party relations. Thus, in the charter of a political party, in order to increase the activity of ordinary party members, there are provided means of encouragement. And a mechanism was created that prevents usurpation of power in the Party, the so-called «1/3 right.» According to these norms, $1 / 3$ of lower-level organizations may initiate a vote of no confidence in top-level executives, and such issues should be considered by the top governing body of such organization. This applies to both the Heads 
of Committees of the primary cells and the Chairman of the Party. In addition, the regional structure of the party introduced primary cells that are created within the streets, neighborhoods, micro-districts in cities or within a village, settlement, united territorial community, city of regional importance $^{17}$. Statutory innovations should also include the extension of the rights of party members to influence the formation of the party's electoral list approved by the congress, as well as the right to challenge decisions of party governing bodies. In this way, ordinary members of the party are given the opportunity to influence the decision-making process within the party ${ }^{18}$.

On the whole, most political parties in Ukraine are characterized by centralization of party management and limited intra-party democracy.

In the electoral period, the activities of a political party are aimed at achieving a certain result, which involves taking into account public opinion, voter motives. One of the main factors that can support voters is the activity of the party leader (the «rating engine» that heads the party's electoral list). On the one hand, identifying a party with a leader facilitates the positioning of a political party in the electoral space, streamlines the choice of citizens, reducing it to the parameter of evaluating the leader's activity, and simplifies it. On the other hand, it encourages the creation of leadership-type parties with authoritarian internal organization and focuses the party's election campaign solely on the personality of the leader and his promises, and not on ideology and programmatic principles.

Given this unambiguous need for domestic parties is the need for their restructuring, which will ensure the formation of an effective organizational structure capable of responding to the current challenges of the political process. Such restructuring implies the replacement of the classic hierarchical structure with a mobile organization that would take into account the regional peculiarities of the party structure and ensure a proper level of intra-democratic democracy with a high range of role-playing functionalization. In this way, bodies responsible for various functions will be created within the party structure, and power will be distributed in proportion between these bodies. In addition, temporary structures of specialists should be created within the party to ensure the management of individual projects aimed at solving specific tasks, especially during the election period. The restructuring of the party structure will ensure the

17 Статут Партії «Українське об’єднання патріотів - УКРОП!». Офіиійний сайт украӥнської партії Украӥнського об'єднання патріотів. URL: http://www.ukrop.com.ua/ uk/about/statut.

${ }^{18}$ Кройтор А. В. Полухіна А. В. Реструктуризація внутрішньопартійної організації як виклик сучасної доби. Актуальні проблеми політики. 2017. Вип. 60. С. 223-234. 
redistribution of power within the party organization, as well as ensure the activity of the members of the lower level of the party structure by reducing the leadership role of the party nucleus in controlling information flows and making management decisions.

Some scholars believe that party restructuring in Ukraine does not happen because parties are more of a leader type and party leader is a party brand without which it is impossible to conduct a successful election campaign. That is why party leaders do not allow for decentralization of internal party management.

However, we must disagree with this view, since restructuring parties does not necessarily lead to a change in party branding. In terms of image technologies, the election campaign may continue to focus on the image of the party leader as a «symbol» of the party, in case such a strategy ensures the party's victory.

Modern party organizations, in their unalterable form, turn into uncompetitive goods, the sale of which is too expensive for their leaders. In view of this, T. Plakhtiy states: «The decline of political parties compels their leaders to appeal to more powerful organizations - oligarchic clans with financial support for access to the media in order to maintain the relevance and awareness of their brand, which for the reasons stated above is not true. This leads to the loss of independence of political parties and the establishment of external control over them by the oligarchic clans, who thus become the main beneficiaries of their activities» ${ }^{19}$. It is through these processes that political parties from the institutions of articulation of the interests of society are transformed into a mechanism of channeling the interests of individual oligarchic groups in the center of decision-making, which in the conditions of a parliamentary-presidential republic is a parliament. As a result, only the core of the organization and the governing bodies on the ground remain in effect.

We cannot but agree with T. Plakhtiy, who argues that the restructuring of Ukrainian political parties involves the choice of: a variable structure of political organizations; dynamic network and principles of its operation; the totality of all its internal organizational processes; systems of control over the flow of internal organizational processes; the order of deployment of the variable structure; concepts of activity of political organizations with a variable structure - a dynamic network that covers the main tasks of the activity, requirements for the activity, structured field of activity,

19 Плахтій Т. Типовий і оптимальний шляхи розвитку політичних організацій за методологією. 2015. 10 липня. Хвиля: веб-сайт. URL: http://hvylya.net/analytics/society/ tipoviy-i-optimalniy-shlyahi-rozvitku-politichnih-organizatsiy-za-metodologiyeyu-adizesa.html. 
methodology of activity, technological process of activity; fundamentals of financing political organizations with a variable structure - a dynamic network ${ }^{20}$.

Such restructuring should not only ensure the effectiveness of parties as an «enterprise» in the political market, but also meet the needs of democratization of the internal structure, which will reduce the level of oligarchicism of the party. Intermediate parties with a high degree of participation in the governance of its members will ensure not only the legitimization of the party elite, but also in the aftermath of the elections, ensure the legitimacy of the entire political system, and therefore its stability and democratization.

It should be noted that after the Revolution of Dignity, there were changes in the technologies of political parties' construction, both those formed before 2013 and those that formed their structures in the revolutionary and post-revolutionary period. V. Karasyov notes: «From the point of view of construction, political parties began to form more from the bottom, based on the active civic position of the people. Parties are intensively engaged in rebranding, recruiting new staff on the basis of active cooperation with new political actors - activists, «new heroes» (ATO participants, volunteers, etc.), public organizations. New parties are horizontal, not vertical, civic rather than leadership parties»» ${ }^{21}$.

Certainly, the main ideological focus of political parties today is focused on patriotic, human rights and integration directions. Parties try to help people protect their rights from arbitrary rule, corruption, injustice. The nature of party activities is also changing. Parties are increasingly working in the field, organizing and actively participating in pickets, rallies, flash mobs, protests. The type of interaction with supporters is also changing. This is facilitated by the active use of social networks and mobile technologies, crowdsourcing and more. However, in contrast to V. Karasyov, A. Kolodiy denies the scale of changes in the processes of party organization in Ukraine, in particular the researcher points out: «The Maidan did not have much influence on the ways of creation of political parties and their typology. The political component of the Maidan was weak and did not respond to the challenges that Ukraine's political system faced. Instead of leading, the leaders of the opposition at the time were adapting, and the public sector

${ }^{20}$ Плахтій Т. Концепція і стратегія реструктуризації політичних партій в Україні. 2016. 19 жовтня. Хвиля: веб-сайт. URL: http://hvylya.net/analytics/society/kontseptsiya-istrategiya-restrukturizatsiyi-politichnih-partiy-v-ukrayini.html.

${ }^{21}$ Політичні партії України: погляд фахівців. Національна безпека і оборона. 2015. № 6-7. C. 155-156. URL: http://www.razumkov.org.ua/uploads/journal/ukr/NSD155156_2015_ukr.pdf. 
could neither identify from among its new political leaders nor create a mass movement on the basis of which a new organized political force would emerge». Conditionally dividing parties into «old» and «new» researcher refers to the new parties «Petro Poroshenko Bloc», «Narodny Front» and «Samopomich» (which gained national significance only after the Maidan), as well as «Opposition Bloc». To the old - «Batkivshchyna, O. Lyashko Radical Party, UU «Svoboda», «Civic Position». Undoubtedly, the BPP is organized under a leader and is a universal type party. This is evidenced by the lack of a clear ideology, and the election platform has actually become a program of party activity. Structurally, the party is organized around a leader, which is the engine of its rating.

«Samopomich» is somewhat more open-minded, closer to civil society and its demands, and a member of the faction on voting. At the same time, the party is approaching two previous parties with a leader, with strong managerial functions.

The analysis of party structures of Ukraine at the present stage of functioning allows to make the following conclusions: parties remain, to a greater extent, financially dependent on oligarchic groups, performing the function of representing the interests of these groups in parliament; for the most part, modern parties are not classical parties, because they do not have extensive networks of primary centers whose activities are formal; parties maintain a centralized, hierarchical structure, with low levels of intra-party democracy.

\section{CONCLUSIONS}

Therefore, given all of the above, a successful political party in Ukraine that would be independent of the oligarchy and based on an extensive decentralized, non-leadership structure could become a party that represents the interests of the middle class. The internal structure of such a party should be based on an adhocratic basis, with a dynamic and extensive management network. T. Plakhtiy notes that participation in party activities should be based on three-level membership: level 1 - members of the organization who systematically participate in the meeting and execute, coordinate, make and implement all decisions; level 2 - candidates for membership of the organization who can optionally attend the meeting with an advisory vote and participate in the implementation of part of the decisions; level 3 supporters who are interested in the activities of the organization and 
optionally take part in activities that it organizes as part of its statutory activities $^{22}$.

At the same time, the structure of the party in different regions of the state should have appropriate units that would work on the solution of highly specialized problems, taking into account the regional peculiarities of the electorate. It should be noted that the structural organization of the party must be variable according to the situation in the external environment. Thus, the main link of the party structure representing the dynamic network is the regional branch of the party. The decision in the party branch of the regional level should be made collectively, through the method of brainstorming, which will allow finding non-standard approaches to solving both current and strategic issues of party functioning.

District and local party units are organized with a small number of permanent members, each of whom is engaged in the implementation of separately set tasks, creating an organizational group that is liquidated or reorganized according to the professional and creative abilities of team members after solving the tasks. This eliminates the need for a hierarchical organization of local party cells based on a permanent structure. The central governing bodies of the party make decisions by coordinating the positions of the regional centers in all directions and profiles of party activity, taking into account the regional specificity.

Therefore, it is precisely through the restructuring of an internal party organization on the basis of democratization that the path to the success and independence of political parties and their transformation into a real institution of articulation and aggregation of interests of society, rather than individual oligarchic groups, will be provided, which will ensure the successful process of democratization of the entire political system of the state system.

\section{SUMMARY}

The article is dedicated to the pressing issue of political science - the study of the intra-party structure and the need for its restructuring in the process of democratization in Ukraine. The specificity of the Ukrainian political parties' internal party organization and the needs of their restructuring in the current conditions of the political process are analyzed. The structures of individual political parties are analyzed on the basis of the study of party charters. It is noted that the main tendency of intra-party

${ }^{22}$ Плахтій Т. Концепція і стратегія реструктуризації політичних партій в Україні. 2016. 19 жовтня. Хвиля: веб-сайт. URL: http://hvylya.net/analytics/society/kontseptsiya-istrategiya-restrukturizatsiyi-politichnih-partiy-v-ukrayini.html. 
functioning is oligarchization of the internal-party structure of the majority of political parties of Ukraine. It was determined that the restructuring of the party structure should be carried out on the basis of democratization of intraparty relations, and decentralization of the system of party management on the basis of building a dynamic, networked party structure, which is an important factor in the democratization of the domestic political system.

\section{REFERENCES}

1. Бутусов Ю. Донецьк в епоху фракційної роздробленості. Дзеркало тижня. 2005. № 15. URL: http://gazeta.dt.ua/ARCHIVE/ donetsk_v_epohu_fraktsiynoyi_rozdroblenosti.html.

2. Гагалюк Б. Концепт «правлячої партії» в умовах парламентаризму: сучасний політичний дискурс. Нова парадигма: Журнал наукових пращь. 2006. Вип. 55. Київ, Вид-во НПУ імені М. П. Драгоманова. С. 152-161.

3. Головатий М. Ф. Професія - політик. Кіїв: Парламентське видво, 2000.88 с.

4. Головатий М. Ф. Соціологія політики: [навч. посіб. для студ. вищ. навч. закл.]. Київ: МАУП, 2003. 504 с.

5. Жданов I., Якименко Ю. Нові обрії української багатопартійності. Дзеркало тижня. 2003. № 24. URL: http://gazeta.dt.ua/POLITICS/novi_obriyi_ukrayinskoyi_bagatopartiynosti.h tml.

6. 3’їзд Бондарчука прийняв рішення про саморозпуск «Нашої України». Дзеркало тижня. 2012. 2 брезня. URL: http://zn.ua/POLITICS/sezd-bondarchuka-prinyal-reshenie-o-samorospuskenashey-ukrainy-118067_.html.

7. За часів президентства Януковича ПР перетворилася на аналог радянської партії. Правда. 2013. 18 березня. URL: http://pravda.if.ua/print.php?id=37382.

8. Конончук С. Г., Ярош О. А. Основні процедури внутрішньопартійної демократії. Аналітичний. Київ: Український незалежний центр політичних досліджень, 2012. 96 с. URL: http://www.ucipr.kiev.ua/userfiles/party_\%20democracy2012.pdfa.

9. Конституція України від 28.06.1996 р. Відомості Верховної Ради. 1996. № 30. С. 141.

10. Кройтор А. В. Полухіна А. В. Реструктуризація внутрішньопартійної організації як виклик сучасної доби. Актуальні проблеми політики. 2017. Вип. 60. С. 223-234. 
11. Лебедюк В. Організаційний баланс ресурсів політичних партій в Україні. Національна бібліотека Украӥни імені B. I. Вернадського: веб-сайт. URL: http://dspace.nbuv.gov.ua/bitstream/ handle/123456789/26799/15-Lebedyuk.pdf?sequence $=1$.

12. Михельс Р. Социология политической партии в условиях демократии. Диалог. 1990. № 5, 9; 1991. № 4. URL: http://www.read.virmk.ru/m/Mixels.htm.

13. Плахтій Т. Концепція і стратегія реструктуризації політичних партій в Україні. 2016. 19 жовтня. Хвиля: веб-сайт. URL: http://hvylya.net/analytics/society/kontseptsiya-i-strategiyarestrukturizatsiyi-politichnih-partiy-v-ukrayini.html.

14. Плахтій T. Типовий i оптимальний шляхи розвитку політичних організацій за методологією. 2015. 10 липня. Хвиля: вебcaŭm. URL: http://hvylya.net/analytics/society/tipoviy-i-optimalniy-shlyahirozvitku-politichnih-organizatsiy-za-metodologiyeyu-adizesa.html.

15. Політичні партії України: погляд фахівців. Національна безпека $i$ оборона. 2015. № 6-7. C. 155-156. URL: http://www.razumkov.org.ua/uploads/journal/ukr/NSD155156_2015_ukr.pdf.

16. Про політичні партії в Україні: Закон України від 05.04.2001 p. № 2365-III (зі змінами). Офіиійний сайт Верховної Ради України. URL: http://zakon2.rada.gov.ua/laws/show/2365-14.

17. Саймон Г. А. Адміністративна поведінка: Дослідження процесів прийняття рішень в організаціях, що виконують адміністративні функції; пер. з англ. Київ: Артек, 2001. 392 с.

18. Статут Всеукраїнського об'єднання «Батьківщина». Офіиійний сайт української партії «Батьківщина». URL: http://byut.com.ua/statute.html.

19. Статут Партії «Українське об’єднання патріотів - УКРОП!». Офіиійний сайт украӥнської партії Украӥнського об 'еднання патріотів. URL: http://www.ukrop.com.ua/uk/about/statut.

20. Статут Партії регіонів. Офіційний сайт украӥнської партії «Партія Регіонів». URL: http://www.partyofregions.org.ua/meet/statute/.

21. Шведа Ю. Р. Теорія політичних партій і партійних систем. Львів: ЦПД, 2002. 528 с.

22. Шевчук О. А. Роль засобів комунікації у формуванні політичних цінностей українського суспільства. Політична наука в Украӥні: стан $i$ перспективи: матеріали всеукраїнської наукової конференції (Львів, 10 - 11 травня 2007). Львів: ЦПД, 2008. С. 183-188. URL: http://postua.info/anisimovych.htm. 
23. Шимонова О. Виборчі списки як індикатор внутрішньопартійної комунікації. Українська національна ідея: реаліі та перспективи розвитку. 2009. Вип. 21. С. 180-184. URL: http://dspace.nbuv.gov.ua/bitstream/handle/123456789/25722/36-

Shimanova.pdf? sequence $=1$.

\section{Information about the author:}

Kroitor A. V.,

$\mathrm{PhD}$ in Political Sciences,

Associate Professor at the Department of Political Theories of the National University «Odessa Law Academy»

2, Academichna str., Odesa, 65009, Ukriane 